\title{
PENGARUH BIMBINGAN KLASIKAL DENGAN METODE JIGSAW TERHADAP KONTROL DIRI SISWA DALAM PENGGUNAAN HANDPHONE DI SEKOLAH PADA KELAS IX SMP NEGERI 7 PEMALANG The Influence Of Gradeical Guidance With Jigsaw Method On The Self Controls Of Students In The Use Of Handphone In Schools In Grade IX SMP Negeri 7 Pemalang
}

\author{
Oleh: Alvin Himawan*, Siti Fitriana** dan Farikha Wahyu Lestari** \\ Bimbingan dan Konseling Fakultas Ilmu Pendidikan \\ Universitas PGRI Semarang \\ e-mail: himawan.alvin@gmail.com
}

\begin{abstract}
ABSTRAK
Penelitian ini dilatar belakangi oleh siswa yang sering membawa handphone ke sekolah digunakan untuk media untuk mencontek, bermain game pada saat pelajaran, dan bermain media sosial pada saat jam pelajaran sehinggi mengakibatkan terhambatnya proses belajar mengajar yang sedang berlangsung. Permasalahan yang dikaji dalam penelitian adalah apakah bimbingan klasikal dengan metode jigsaw terhadap kontrol diri siswa dalam pengunaan handphone di sekolah?. Jenis penelitian ini adalah penelitian kuantitatif desain quasi experimental bentuk nonequivalent control group design dengan model pre-test post-test control group design.. Populasi penelitian adalah siswa kelas IX SMP Negeri 7 Pemalang. Sampling yang digunakan dalam penelitian ini adalah cluster random sampling. Teknik analisis data yang digunakan yakni analisis presentase dengan $U j i t$ (t-test). Hasil analisis skala kontrol diri dalam penggunaan handphone pada kelompok eksperimen dengan menggunakan uji-t hasil post-test menunjukan rata-rata kelompok eksperimen sebesar 83,67 dan kelompok kontrol 77,2. Sehingga terjadi peningkatan rata-rata pada kelompok eksperimen sebesar 10,5. Pada penghitungan uji- $t$ diperoleh hasil thitung $(3,11)>$ ttabel $(2,000)$, maka hipotesis kerja (Ha) diterima dan hipotesis nihil (Ho) ditolak. Disimpulkan bahwa bimbingan klasikal dengan metode jigsaw berpengaruh terhadap kontrol diri siswa dalam penggunaan handphone kelas IX SMP Negeri 7 Pemalang.
\end{abstract}

Kata Kunci: Bimbingan Klasikal, Jigsaw, Kontrol Diri Siswa Dalam Penggunaan Handphone

\begin{abstract}
This research is motivated by students who often bring mobile phones to school used for media for cheating, playing games during lessons, and playing social media during high school hours resulting in delays in the ongoing teaching and learning process. The problem examined in this research is whether gradeical guidance with the jigsaw method of student self-control in the use of mobile phones at school ?. This type of research is a quantitative research design quasi experimental form nonequivalent control group design with a model of pre-test post-test control group design. The study population was grade IX students of SMP Negeri 7 Pemalang. The sampling used in this study is cluster random sampling. The data analysis technique used is percentage analysis with t-test. The results of self-control scale analysis in the use of mobile phones in the experimental group using the t-test post-test results showed an average of the experimental group of 83.67 and a control group of 77.2. So that
\end{abstract}

*Alvin Himawan, **Siti Fitriana dan ***Farikha Wahyu Lestari

Bimbingan dan Konseling Fakultas Ilmu Pendidikan

Universitas PGRI Semarang 
there was an increase in the average in the experimental group by 10.5. In the t-test calculation, the result of t-count $(3.11)>t$-table $(2,000)$, the work hypothesis (Ha) is accepted and the null hypothesis (Ho) is rejected. It was concluded that gradeical guidance with the jigsaw method affected student self-control in the use of cellphones in grade IX of SMP Negeri 7 Pemalang.

Keywords: Gradeical Guidance, Jigsaw, Student Self-Control in The Use of Mobile Phones.

\section{PENDAHULUAN}

Di era globalisasi saat ini informasi merupakan bagian yang sangat penting dan dibutuhkan oleh setiap manusia terutama bagi kalangan pelajar. Hal ini dikarenakan dunia pendidikan juga mengalami kemajuan. Segala sumber informasi sudah banyak disebarkan melalui media cetak mapun media elektronik, salah satunya adalah handphone. Pencarian tersebut dapat dilakukan dimana saja dan kapan saja tanpa membuang waktu yang lama. Sehingga siswa tidak kesulitan dalam mencari informasi yang berkaitan dengan materi sekolah. Cara yang cukup mudah tersebut menjadikan siswa menyepelekan pelajaran serta siswa menjadi ketergantungan terhadap handphone.

Dari hasil survei yang dilakukan oleh the Headmasters' and Headmistresses' Conference (HMC) yang bermitra dengan Digital Awarness UK (DAUK). Di kutip dari kompas.com Oktober 2016 dilakukan terhadap 2.750 remaja berusia $11-18$ tahun.Hasilnya, sebanyak $45 \%$ remaja mengaku mengecek ponsel mereka sebelum tidur malam. $32 \%$. Orang tua ternyata tidak menyadari kebiasaan anaknya itu, 68 persen remaja yang sering menggunakan ponsel sebelum tidur, $10 \%$ anak-anak merasa tertekan atau gelisah jika tidak mengecek ponsel sebelum tidur. 94\%, remaja mengecek media sosial mereka pergi ke tempat tidur dan $42 \%$ menyimpan ponsel di samping tempat tidur pada malam hari. Dampak negatif dari penggunaan handphone yaitu remaja dengan mudah mendapat kiriman atau download situs-situs porno dari internet melalui handphone. Remaja yang terlalu hobi dengan game yang ada di dalam fasilitas handphone cenderung tidak peduli dengan situasi dan kondisi yang sering berakibat berkurangnya waktu belajar, sehingga menurunkan prestasi belajarnya.

Kontrol diri menurut Messina dan Messina (dalam Gunarsa 2004:251) menyatakan bahwa kontrol diri adalah seperangkat tingkah laku yang berfokus pada keberhasilan mengubah tingkah laku yang berfokus pada keberhasilan mengubah diri pribadi, keberhasilan menangkal pengrusakan diri (self destructive), perasaan mampu pada diri sendiri, perasaan mandiri (autonomy) atau bebas dari pengaruh orang lain, kebebasan menentukan tujuan, kemampuan untuk memisahkan perasaan dan pikiran rasional, serta seperangkat tingkah laku yang berfokus pada tanggung jawab atas diri pribadi. Kontrol diri sangat erat kaitannya dengan adanya pengendalian individu dalam melakukan berbagai hal yang diinginkan. Individu akan merasa lebih baik apabila setiap langkah yang dilakukan dapat diimbangi dengan kontrol 
diri yang positif sehingga hasil yang dicapai dapat optimal.

Menurut Aini (dalam Umi 2018:65)Siswa yang memiliki kontrol diri tinggi akan menggunakan waktu yang mengarah pada perilaku yang lebih utama yaitu belajar. Sedangkan siswa yang memiliki kontrol diri rendah yaitu siswa tersebut tidak mampu mengatur dan mengarahkan perilakunya seperti secara diam-diam siswa mengoperasikan handphone pada saat jam pelajaran berlangsung yang digunakan untuk bermain game online serta membuka media sosial seperti BBM, instagram, path, twitter, facebook. Menurut Ghufron dan Risnawita (2017:32) mengemukakan beberapa faktor yang mempengaruhi kontrol seperti faktor internal, faktor yang ikut andil terhadap kontrol diri adalah usia. Semakin bertambah usia maka semakin baik kemampuan mengontrol diri seseorang. Faktor eksternal diantaranya adalah lingkungan keluarga. Lingkungan keluarga terutama orang tua menentukan bagaimana mengontrol diri seseorang.

Penelitian hasli Yutifa, dkk (2015:1144) media elektronik membawa pengaruh yang sangat besar, kehadiran media elektronik seperti handphone turut mempengaruhi remaja melakukan perbuatan yang tidak sesuai dengan norma susila. Penggunaan handphone disamping memperlancar komunikasi antar individu dalam kegiatan pekerjaan, mempererat silaturahmi dengan relasi atau teman, remaja menggunakan handphone sebagai tempat untuk mencari sesuatu yang berbau pornografi. Karena remaja memiliki rasa ingin tahu lebih maka mengakibatkan remaja memanfaatkan media handphone sebagai alat untuk mencari tahu atau mengakses pornografi. Remaja dalam hal ini harus memiliki kontrol diri yang baik, apabila kontrol dirinya rendah maka akan menjadi perilaku menyimpang dalam kehidupan sehari-hari.

Beberapa alternatif pelaksanaan layanan yang dapat digunakan dalam sekolah untuk mengatasi rendahnya kontrol diri siswa dalam penggunaan handphone diantaranya melalui bimbingan klasikal. Menurut Brawer (dalam Winkel dan Hastuti 2012:545) menggunakan bimbingan klasikal sebagai sarana mempersiapkan siswa untuk mengatur berbagai bidang kehidupannya supaya bermakna dan memberikan kepuasan, seperti bidang kesehatan, bidang pekerjaan, bidang kehidupan keluarga, bidang kehidupan bermasyarakat, dan bidang rekreasi. Fungsi dari bimbingan klasikal adalah fungsi preventif atau pencegahan adalah fungsi bimbingan untuk menghindarkan diri dari terjadinya tingkah laku yang tidak diharapkan dan ataupun membahayakan dirinya dan orang lain.

Pemahaman kontrol diri siswa dalam penggunaan handphone diasumsikan dapat melalui bimbingan klasikal dengan metode jigsaw. Berdasarkan hasil penelitian Agustina, dkk (2013:66) bahwa penggunaan metode pembelajaran jigsaw berbentuk handout dapat meningkatkan aktivitas dan prestasi belajar pada materi pokok hidrokarbon kelas XC SMA Negeri 1 Gubug. Jadi dengan diberikan metode jigsaw ini siswa mampu aktif dalam proses bimbingan dan mudah memahami mengenai dampak dari penggunaan handphone agar siswa dapat mengontrol dirinya untuk penggunaan handphone di kelas maupun di luar kelas. 


\section{METODE PENELITIAN}

Penelitian ini menggunakan metode kuantitatif tidak berupa kalimat-kalimat atau pernyataan-pernyataan tetapi berupa angka yang berasal dari skala kontrol diri dalam penggunaan handphone. Metode yang digunakan dalam penelitian ini adalah kuantitatif dengan dengan pendekatan Desain yang digunakan dalam penelitian ini adalah quasi-experimental designs dengan bentuk nonequivalent control group design. Rencana penelitian dengan menggunakan pretest-postest control group design dalam penelitian ini terdapat dua kelompok yang dipilih tidak secara rondom, kemudian diberikan pretest untuk mengetahui adakah perbedaan antara kelompok eksperimen dan kontrol (Sugiyono 2018:77).

Dalam penelitian ini populasi dikenakan pada siswa kelas IX SMP Negeri 7 Pemalang. Dengan jumlah populasi 210 siswa kelas IX SMP Negeri 7 Pemalang diambil 30 siswa untuk digunakan untuk sampel. Teknik pengambilan sampel dalam penelitian ini yaitu dengan menggunakan cluster random sampling yaitu cara pengambilan sampel bukan didasarkan pada individu, tetapi lebih didasarkan pada kelompok, daerah atau kelompok subjek yang secara alami berkumpul bersama (Arikunto, 2013: 185).

Menurut Arikunto (2010:109) sampel adalah sebagian atau wakil populasi yang di teliti. Dalam penelitian ini peneliti mengambil sampel dengan teknik cluster random sampling yaitu memilih satu kelas tertentu dari populasi yang ada untuk dijadikan kelompok eksperimen dan setelah diundi dengan menggunakan gulungan kertas diketahui oleh guru BK disekolah dan akhirnya terpilih dua kelas, satu kelas kelompok eksperimen dan kelompok kontrol.

Variabel penelitian ini meliputi pemahaman kontrol diri dalam penggunaan handphone siswa dengan bimbingan klasikal menggunakan metode jigsaw. Instrumen yang digunakan pada penelitian ini adalah skala psikologis konntrol diri dalam penggunaan handphone daari butir item 32 yang telah di uji validitas dan reliabilitas dilakukan untuk menguji instrumen penelitian. Pengujian ini dilakukan dengan cara menyebar instrumen. Identifikasi peningkatan kontrol diri dalam penggunaan handphone siswa disajikan dalam bentuk tabel deskriptif prosentase dengan setiap kategori.

\section{HASIL PENELITIAN DAN PEMBAHASAN}

Pengaruh Bimbingan Klasikal dengan Metode Jigsaw Terhadap Kontrol Diri Siswa dalam Penggunaan Handphone.

Adapun deskripsi data hasil pre-test sebagai berikut:

Dari hasil pre-test mengeai kontrol diri siswa dalam penggunaan handphone kelas IX SMP Negeri 7 Pemalang, kelompok kontrol terdapat dua siswa termasuk dalam kategori "sangat rendah" dengan presentase 7\%. 13 siswa termasuk kategori "rendah" dengan presentase $43 \%$. dan 15 siswa termasuk dalam kategori "tinggi". Rata-rata kontrol diri dalam penggunaan handphone 76,03. termasuk kategori rendah. Sedangkan pada kelompok eksperimen terdapat 4 siswa termasuk dalam kategori "sangat rendah" dengan presentase $15 \%$. 10 siswa termasuk kategori "rendah" dengan presentase $48 \%$.

*Alvin Himawan, **Siti Fitriana dan ***Farikha Wahyu Lestari

Bimbingan dan Konseling Fakultas Ilmu Pendidikan

Universitas PGRI Semarang 
dan 13 siswa termasuk dalam kategori "tinggi". Rata-rata kontrol diri dalam penggunaan handphone 73,62 . termasuk kategori rendah

Adapun deskripsi data hasil post-test sebagai berikut:

Dari hasil post-test mengeai kontrol diri siswa dalam penggunaan handphone kelas IX SMP Negeri 7 Pemalang, kelompok kontrol terdapat bahwa 16 siswa pada kategori "tinggi" dengan presentase $53 \%, 13$ (tiga belas) siswa pada kategori "rendah" dengan presentase $43 \%$, dan 1 siswa pada kategori "sangat rendah" dengan presentase $3 \%$. Rata-rata kontrol diri dalam penggunaan handphone 83,67 termasuk kategori tinggi. Sedangkan pada kelompok eksperimen terdapat 21 siswa termasuk dalam kategori "tinggi" dengan presentase $78 \%$, dan 6 siswa termasuk dalam kategori "rendah" dengan persentase $22 \%$. Rata-rata kontrol diri dalam penggunaan handphone 77,2. termasuk kategori rendah.

\begin{tabular}{|l|l|l|l|}
\hline Interval & $\begin{array}{l}\text { Kategor } \\
\text { i }\end{array}$ & $\begin{array}{l}\text { Ekseper } \\
\text { imen }\end{array}$ & Kontrol \\
\hline $\begin{array}{l}104- \\
128\end{array}$ & $\begin{array}{l}\text { Sangat } \\
\text { Tinggi }\end{array}$ & 0 & 0 \\
\hline $\begin{array}{l}80- \\
103\end{array}$ & Tinggi & 21 & 16 \\
\hline $56-79$ & Rendah & 6 & 13 \\
\hline $32-55$ & $\begin{array}{l}\text { Sangat } \\
\text { Rendah }\end{array}$ & 0 & 1 \\
\hline Jumlah & 27 & 30 \\
\hline
\end{tabular}

Berdasarkan perhitungan uji-t diperoleh hasil $t_{\text {nit }}$ sebesar 3,113 sementara $t_{t_{1}} \quad$ dengan $\mathrm{db}(\mathrm{n} 1+\mathrm{n} 2)-2=$ $(27+30)-2=55$ dengan taraf signifikansi $5 \%$ (0.05) sebesar 2,000. Karena jumlah $t_{\text {nit }}>t_{t_{1}}$ maka Ho ditolak dan $\mathrm{Ha}$ diterima, sehingga hipotesisnya (Ha) berbunyi "ada pengaruh bimbingan klasikal dengan metode jigsaw untuk kontrol diri dalam penggunaan handphone siswa kelas IX SMP Negeri 7 Pemalang tahun pelajaran 2018/2019" diterima. Sedangkan hipotesis nihil $\left(\mathrm{H}_{\mathrm{o}}\right)$ yang berbunyi "tidak ada pengaruh bimbingan klasikal dengan metode jigsaw untuk kontrol diri dalam penggunaan handphone siswa kelas IX SMP Negeri 7 Pemalang tahun pelajaran 2018/2019" ditolak pada taraf signifikansi 5\%. Dari penjelasan di atas, maka dapat disimpulkan bahwa ada pengaruh bimbingan klasikal dengan metode jigsaw untuk kontrol diri dalam penggunaan handphone siswa kelas IX SMP Negeri 7 Pemalang tahun pelajaran 2018/2019 karena memiliki perbedaan yang signifikan dilihat dari hasil perhitungan uji t.

Berdasarkan hasil perhitungan uji hipotesis diperoleh hasil $t_{\text {hitung }}=3,113$ Selanjutnya dikonsultasikan dengan $t_{\text {tabel }}$ taraf signifikansi 5\% (0.05) yaitu 2,000. Hal tersebut menunjukkan bahwa $t_{\text {hitung }}=3,113$ $>t_{\text {tabel }}=2,000$. Atas dasar perhitungan tersebut maka hipotesis alternatif (Ha) yang berbunyi "ada pengaruh bimbingan klasikal dengan metode jigsaw terhadap kontrol diri siswa dalam penggunaan handphone siswa kelas IX SMP Negeri 7 Pemalang tahun pelajaran 2018/2019" diterima kebenarannya pada taraf signifikansi $5 \%$.

Bimbingan klasikal akan lebih lebih menarik dengan metode jigsaw dari pada hanya dengan metode ceramah karena siswa akan lebih cepat bosan ketika hanya menggunakan metode ceramah. Dengan metode ini dirasa juga lebih efektif karena siswa lebih aktif dalam mengikuti layanan. 
Metode jigsaw yang diberikan adalah mendiskusikan tiap kelompok mengenai materi yang berkenaan langsung dengan kontrol diri penggunaan handphone. Dengan diberikannya bimbingan klasikal dengan metode jigsaw, membuat siswa mampu meningkatkan pemahamannya mengenai kontrol diri dalam penggunaan handphone dengan lebih mudah karena dalam metode jigsaw siswa di tuntut aktif dalam setiap diskusi kelompok kecil yang sudah dibagi untuk memudahkan siswa memahami setiap materi yang sudah dibagikan sehingga siswa mampu merubah perilakunya.

Fakta di lapangan diperoleh pada saat treatment bimbingan klasikal dengan metode jigsaw, sebelum diberikan treatment dan setelah diberikan treatment dengan bimbingan klasikal dengan metode jigsaw pada kelompok eksperimen mengalami kenaikan atau perubahan sebesar 285 poin berdasarkan hasil pre-test dan post-test. Dari hasil tersebut dapat disimpulkan bahwa terjadi perubahan karena ketika treatment sudah cukup baik dan tidak ada halangan dalam pelaksanaan pemberian trearment. Hal ini, didukung oleh penelitian yang telah dilakukan oleh hasil penelitian Agustina, dkk (2013:66) bahwa penggunaan metode pembelajaran jigsaw berbentuk handout dapat meningkatkan aktivitas dan prestasi belajar pada materi pokok hidrokarbon kelas XC SMA Negeri 1 Gubug.

\section{KESIMPULAN}

Berdasarkan hasil perhitungan uji hipotesis diperoleh hasil $t_{\text {hitung }}=3,1133$. Selanjutnya dikonsultasikan dengan $t_{\text {tabel }}$ taraf signifikansi 5\% (0.05) yaitu 2,000. Hal tersebut menunjukkan bahwa $t_{\text {hitung }}=3,113$ $>t_{\text {tabel }}=2,000$. Atas dasar perhitungan tersebut maka hipotesis alternatif ( $\mathrm{Ha}$ ) yang berbunyi "ada pengaruh bimbingan klasikal dengan metode jigsaw terhadap kontrol diri siswa dalam penggunaan handphone siswa kelas IX SMP Negeri 7 Pemalang tahun pelajaran 2018/2019" diterima kebenarannya. Dengan demikian menunjukkan bahwa bimbingan klasikal dengan metode jigsaw dapat meningkatkan pemahaman tentang kontrol diri siswa dalam penggunaan handphone.

\section{DAFTAR PUSTAKA}

Agustina, Erna, dkk. 2013. Penggunaan Metode Pembelajaran Jigsaw Berbantuan Handout Untuk Meningkatkan Aktivitas Dan Prestasi Belajar Siswa Pada Materi Pokok Hidrokarbon Kelas Xc Sma Negeri 1 Gubug Tahun Ajaran 2012/2013. Jurnal Pendidikan Kimia. 2(1). https://jurnal.fkip.

uns.ac.id/index.php/kimia/article/vie w/2775 /1907. Diunduh pada 7 Februari 2019.

Arikunto, Suharsimi. 2010. Prosedur Penelitiab Suatu Pendekatan Praktik. Jakarta: PT Rineka Cipta. Feist,Gregory. 2008. Theories of Personality. Yogyakarta: Pustaka Pelajar.

Diplan. Peningkatan Kemampuan Membaca Pemahaman dengan Strategi Pemecahan Masalah Siswa Kelas V SDN 5 Panarung Palangka Raya.(Tesis). DISERTASI dan TESIS Program Pascasarjana UM, 2009. 
Ghufron, M. Nur dan Risnawati Rini. 2014. Teori-Teori Psikologi. Jogjakarta: ArRuzz Media.

Gunarsa, Singgih. 2004. Dari Anak sampai Usia Lanjut. Jakarta: PT. BPK Gunung Mulia.

Jailani, Muhammad. 2019. Hubungan Status Sosial Ekonomi Orang Tua Terhadap Motivasi Anak Untuk Berwirausaha. Pedagogik: Jurnal Pendidikan, 14(1):35-42.

Maharani, Dian. Dampak buruk ponsel bagi remaja dan cara mengatasinya. https://lifestyle.kompas.com/read/201 6/10/10/170700423/dampak.buruk.po nsel.bagi.remaja.dan.cara.mengatasin ya?page=all. Jawa Tengah. Diakses pada 30 Januari 2019.

Ningsih, Ayu Putri \& Diplan. 2018. Konseling Kelompok Dengan Teknik Relaksasi Kesadaran Indera Untuk Meningkatkan Kontrol Diri Terhadap Emosi Marah Pada Remaja di Panti Sosial Bina Remaja Palangka Raya Suluh: Jurnal Bimbingan Dan Konseling, 3(2):12-18.

Riadin, Agung \& Cici Liani Fitriani. 2018. Upaya Meningkatkan Hasil Belajar Ipa Menggunakan Model Pembelajaran Kooperatif Tipe Jigsaw Dengan Berbantuan Media Alat Peraga Konkret Pada Peserta Didik Kelas V SDN-4 Kasongan Baru Tahun Pelajaran 2016/2017. Pedagogik: Jurnal Pendidikan 13(2):1-5.

Setiawan, M Andi. 2015. Model konseling kelompok dengan teknik problem solving untuk meningkatkan selfefficacy akademik siswa. Jurnal Bimbingan Konseling 4(1).
Sugiyono. 2018. Metode Penelitian Kuantitatif, Kualitatif, dan $R \& D$. Bandung: Alfabeta cv.

Umi, Sys Maf'qhul, dkk. 2018. Pengaruh layanan bimbingan kelompok dengan teknik self management terhadap kontrol diri siswa dalam penggunaan handphone kelas xi sma mardisiswa. Semarang. Jurnal Empati. 5(1). Hal 64-70. http://journal.upgris.ac.id /index.php/EMPATI/article/view/293 2/ 2109. Diunduh pada 28 Agustus 2019.

Ursia, Nella Rega, dkk. Prokrastinasi akademik dan self-control pada mahasiswa skripsi fakultas psikologi Universitas Surabaya. Surabaya. Jurnal hubsasia. 17(1). Hal 1-18. http://hubsasia.ui.ac.id/download/arti cle/178. Diunduh pada 1 Februari 2019.

Winkel dkk, 2012. Bimbingan dan Konseling di Institusi Pendidikan. Jogjakarta: Media Abadi.

Yutifa,Hasli, Dkk. Hubungan Paparan Pornografi Melalui Elektronik Terhadap Perilaku Seksual Remaja. Riasu. Jurnal Ilmu Keperawatan. 2(2). Hal 1141-1148. https://www.neliti.com/publications/1 86419/hubungan-paparan-pornografimelalui-elektronik-terhadap-perilakuseksual-remaja. Diunduh pada tanggal 31 Januari 2019.

*Alvin Himawan, **Siti Fitriana dan ***Farikha Wahyu Lestari 